\section{Associations between time spent traveling in motor vehicles and physical activity in Colombian adults from urban areas}

\author{
Asociaciones entre el tiempo de viaje en vehículos \\ motorizados y la actividad física en adultos \\ colombianos de zonas urbanas
}

\begin{abstract}
Associações entre o tempo gasto em viagens em veículos motorizados e atividade física em adultos colombianos de áreas urbanas
\end{abstract}

Diana C. Paez 1

Luis F. Gomez 2

Christina Mallarino 2

Carlos M. Arango 3

Alberto Flórez 2

Andrew Nylander 1

Diana C. Parra ${ }^{1}$

\author{
1 Brown School, Washington \\ University in St. Louis, U.S.A. \\ 2 Pontificia Universidad \\ Javeriana, Bogotá, Colombia. \\ 3 University of West Florida \\ Pensacola, U.S.A. \\ Correspondence \\ D. C. Paez \\ Prevention Research Center \\ in St. Louis, Brown School, \\ Washington University in \\ St. Louis. \\ 3545 Lafayette Av., St. \\ Louis, MO 63104, U.S.A \\ paez.d.carolina@gmail.com
}

\section{Abstract}

Sedentary behaviors are associated with less physical activity. Little evidence exists about this association and its relation with commuting time in Latin America. This study examined the association between time spent traveling in motor vehicles and physical activity levels in the domains of leisure time physical activity and transportation, among Colombian adults in urban areas. A secondary data analysis of the 2010 National Nutrition Survey was conducted. Time spent traveling in motor vehicles and physical activity were assessed using the International Physical Activity Questionnaire. Binary logistic regressions were conducted. Time spent traveling in motor vehicles for 120 minutes or more was reported among $27.6 \%$ of the sample. The prevalence of walking and bicycling as a means of transportation for at least 150 minutes per week was $34 \%$ and $4.4 \%$, respectively. Achieving at least 150 minutes of leisure time physical activity a week was reported by $18.4 \%$ of the sample. This study suggests negative associations between time spent traveling in motor vehicles and active transport, with significant trend associations in stratified analyses. No significant associations were found between time spent traveling in motor vehicles and leisure time physical activity.

Motor Activity; Sedentary Lifestyle;

Motor Vehicles

\section{Resumen}

Comportamientos sedentarios se asocian con una menor actividad física. Existen pocas evidencias sobre esta asociación en relación con el tiempo de viaje en América latina. Se examinó la asociación entre el tiempo de viaje en vehículos motorizados y los niveles de actividad física en los dominios de actividad física en el tiempo libre y transporte, en adultos colombianos de zonas urbanas. Se realizó un análisis de datos secundarios de la Encuesta Nacional de Nutrición de 2010. El tiempo de viaje en vehículos motorizados y actividad física se evaluó a través del Cuestionario Internacional de Actividad Física. Se llevaron a cabo regresiones logísticas binarias. Tiempo de viaje en vehículos motorizados durante 120 minutos o más, fue reportado por el 27,6\% de la muestra. La prevalencia de caminar y montar en bicicleta como medio de transporte fue de $34 \%$ y 4,4\%, respectivamente. Realizar por lo menos 150 minutos a la semana de actividad física en el tiempo libre fue reportado por el 18,4\% de la muestra. Este estudio sugiere asociaciones negativas entre tiempo de viaje en vehículos motorizados y transporte activo, con tendencias significativas en análisis estratificados. No hubo diferencias significativas entre tiempo de viaje en vehículos motorizados y actividad física en el tiempo libre.

Actividad Motora; Estilo de Vida Sedentário; Vehículos a Motor 


\section{Background}

Recent estimates have found that the failure to meet the minimum recommended amount of physical activity for health (i.e., 150 minutes of moderate or 75 minutes of vigorous physical activity a week) contributes to between $6 \%$ to $10 \%$ of four major non-communicable diseases worldwide (coronary heart disease, type 2 diabetes, and breast and colon cancer) 1. In addition, physical inactivity was responsible for 5.3 million of the 57 million deaths due to chronic disease globally in 20081 . The most recent National Nutrition Survey of Colombia showed that $53.5 \%$ of adults aged 18 to 64 years meet physical activity recommendations between the combined domains of leisure and transportation time 2 . These physical activity levels were mainly related to walking for transportation $33.8 \%$ engaged in at least 150 minutes during the last seven days). Conversely, leisure time physical activity and biking as a means of transportation had lower prevalence. Only $19.9 \%$ and $5.6 \%$ of participants had engaged in at least 150 minutes of biking or leisure time physical activity respectively during the seven days that preceded the survey 2 .

An emerging body of evidence has shown that sedentary behaviors such as sitting in cars are associated with an increased risk of chronic diseases independent of physical activity levels $3,4,5,6$. Time spent traveling in motor vehicles including not only private cars and motorcycles, but also public transportation, may be of relevance to public health due to the influence of urban environmental attributes on behavior ${ }^{7}$. This may be especially relevant in Colombia since approximately $30 \%$ of its population spends 150 minutes or more per week traveling in motor vehicles 8 . Despite the fact that rates of private motor vehicle ownership are lower in Latin America compared to high-income countries 9 , the percentage of car sales in Colombia has increased considerably since 2009 10. During the first trimester of 2011 an increase of $54.4 \%$ in car sales was reported compared to the same period in 2010 10. Moreover, the average duration of trips in motor vehicles (including public transportation) has increased in certain Colombian cities including Bogota, where average travel time increased from 50 minutes in 2002 to 64 minutes in $2011^{11}$, particularly affecting the underserved population that lives in urban peripheries 9 .

Evidence from the International Physical Activity Study showed that people who reported low levels of physical activity were three times more likely to be in the highest sitting quintile compared to those reporting high levels of physical activity 12 . A recent study conducted in the
Unites States showed that commuting distance was negatively associated with physical activity and cardiorespiratory fitness 13. Most of the evidence related to the association between time spent traveling in motor vehicles and physical activity has focused on active transportation and car use in high-income countries 14,15,16,17. These studies concluded that the travel patterns of those who do not commute by car and use public transportation demonstrate a higher level of physical activity during transportation 18 . Moreover, car ownership and use are consistently correlated with lower levels of physical activity, mainly walking and cycling 19 . Nevertheless, to date, evidence of the associations between time spent traveling in motor vehicles and physical activity still remains limited, particularly in Latin American urban contexts, which have been characterized by a rapid and informal urban growth, a lack of integrated public transport systems, and social and economic disparities 20. This is illustrated by the fact that walking or bicycling for transportation usually occurs out of necessity, rather than choice 21,22 . Therefore, the aim of this study is to assess the associations between time spent traveling in motor vehicles and physical activity in the domains of transportation (walking and bicycling) and leisure time physical activity among Colombian adults living in urban areas.

\section{Methods}

\section{Study design and data source}

A secondary data analysis of the 2010 National Nutrition Survey of Colombia (ENSIN) was conducted 2. The main objective of the ENSIN was to establish the prevalence of nutritional indicators and some health conditions in the Colombian population. This survey had a multistage, probabilistic and stratified sampling design that included national and sub-regional representation with an oversampling of rural areas. Logistical and technical details of the ENSIN can be found elsewhere 2 . For the present study, data was used from 7,313 adults between the ages of 18 and 64 who lived in urban locations with more than 82,000 inhabitants and had complete information about time spent traveling in motor vehicles, physical activity and covariates. The first criterion was established given the particular urban dynamics found in Colombia ${ }^{10}$. In addition, participants with disabilities were not included, since they have different mobility patterns that do not fall under the scope of this study. 
The ENSIN used a face-to-face questionnaire methodology in order to inquire about several topics, including those variables described in this study. Both outcome and exposure variables were measured by trained personnel using a Spanish version of the International Physical Activity Questionnaire (IPAQ) long form survey. The questions regarding physical activity levels were culturally validated and only included the leisure time physical activity and the transportation domains, as was recommended for Latin America by several researchers 23 . Special emphasis was made in training and procedure handbooks to avoid an overlap of information in the physical activity domains. For example, the ENSIN participants were instructed not to report activities already reported under a different domain ${ }^{2}$. All participants were asked to provide oral informed consent.

\section{Outcome variables}

For this study we only included the leisure time and transportation (walking and bicycling) domains of the IPAQ. For these domains only spells of at least 10 minutes were included in the analyses.

The domain "leisure time physical activity" was classified in two categories based on the global recommendation of physical activity for health 25: participation in at least 150 minutes of physical activity of moderate intensity or $75 \mathrm{~min}$ utes of vigorous physical activity in the last seven days during leisure time (yes or no).

For the purposes of analysis, two types of activities were derived from the transportation domain: walking for transportation, and bicycling for transportation. Walking as a means of transportation was classified into two categories, depending on whether participants reported having walked at least 150 minutes in the last seven days (yes or no). The same criterion was used for bicycling as a means of transportation.

\section{Exposure variable}

The weekly frequency of time spent traveling in motor vehicles, namely buses, cars, or motorcycles, was measured. In the absence of previous evidence on this subject, we categorized this variable in the following ranges: (a) 0 minutes, (b) 1 to 59 minutes, (c) 60 to 119 minutes, and (d) 120 minutes or more. These categories were created in order to obtain an even distribution of the sample.

\section{Covariates}

Gender, age, level of education, socioeconomic position, occupation and urbanization level were included as covariates in the analysis; these were assessed via self-reporting.

Education level was classified into three categories: (1) elementary school or less, (2) incomplete secondary school and (3) secondary school or more. Age was categorized into the following groups: 18 to 29 years, 30 to 49 years and 50 to 64 years.

Socioeconomic position was determined by the ENSIN using an adapted score of the SISBEN (Identification System of Potential Beneficiaries of Social Programs) index, which is based on health conditions, family education profile, household conditions and social vulnerability 26 . The following four categories were established based on previous studies: (1) low, (2) low-middle, (3) middle and (4) upper-middle 24.

The occupation covariate was classified into five categories: (1) working, (2) searching for a job, (3) studying, (4) homemaker and (5) retired.

Four categories were developed to classify urbanization levels, taking into consideration the number of inhabitants of each urban area included in the survey: (1) 82,000 to 288,000 inhabitants, (2) 388,000 to $1,027,000$ inhabitants, (3) 1,190,000 to $3,432,000$ inhabitants, and (4) the metropolitan area of Bogota, with 7,674,366 inhabitants 27 . These population size intervals are not continuous due to the gaps in the population distribution among the different urban settings.

\section{Statistical analysis}

Bivariate analyses were conducted to find associations between selected socio-demographic characteristics and the outcome and exposure variables. The associations between time spent traveling in motor vehicles and leisure time physical activity and transportation (walking and bicycling) were assessed using binary logistic regression after adjusting for potential confounders. Separate models were run and stratified by gender, age, urbanization level and occupation and were adjusted by potential confounders. In this case, urbanization level and occupation variables were converted into dichotomous variables. For age, the second and third categories were combined into one. For urbanization level, categories 1 and 2 were coded as the lowest urbanization level and categories 3 and 4 as the highest urbanization level. For occupation the categories working and studying were combined into one. The categories of searching for a job, homemaker and retired were combined into 
one category (not working/not studying). Multicollinearity was assessed using a tolerance test and was ruled out. All of the statistical analyses were conducted in 2012 and took into account the complexity of sampling design using Stata 12 (Stata Cop., College Station, USA).

\section{Results}

\section{Study population}

Of the 7,313 participants included in this study, the majority were female and aged between 30 and 49 . Around $35 \%$ of participants lived in urban areas with populations of between 82,000 and 288,000 and $47.5 \%$ had incomplete secondary education. The upper middle socioeconomic position constituted $45.7 \%$ of the population, followed by the low socioeconomic position with $29.8 \%$. Most of the participants had worked or studied in the last seven days (Table 1).

\section{Prevalence of time spent traveling in motor vehicles by selected characteristics}

The prevalence of time spent traveling in motor vehicles was the following: $17.7 \%$ spent $0 \mathrm{~min}$ utes, $29.7 \%$ spent 1 to 59 minutes, $25 \%$ spent 60 to 119 minutes and $27.6 \%$ spent 120 minutes or more per day on transportation in motorized vehicles (Table 1).

For the highest category of time spent traveling in motor vehicles (120 minutes or more), the prevalence was significantly higher in the following groups: males (34\%), ages 30 to 49 (30.1\%), highest levels of urbanization (43.2\%), secondary education or more (34\%), upper-middle socioeconomic position (31.1\%), and those working (31.4\%).

\section{Prevalence of physical activity by selected characteristics}

Table 2 shows that the prevalence of walking as a means of transportation for at least $150 \mathrm{~min}$ utes per week was $34 \%$. It was significantly higher among males (38\%), those in the 50 to 64 age group $(35.7 \%)$, those living in the least urbanized areas $(41.2 \%)$, those searching for a job $(40.1 \%)$ and among those who reported 0 minutes as the time they spent traveling in motor vehicles (42.1\%).

The prevalence of cycling as a means of transportation for at least 150 minutes per week was $4.4 \%$, and was significantly higher in males (9.1\%), those with incomplete secondary schooling $(5.4 \%)$, those living in the least urbanized ar- eas $(4.5 \%)$, those in low socioeconomic positions (5.7\%), among those working or studying (5.6\%), and those who reported 0 minutes as the time they spent traveling in motor vehicles (12.3\%).

The prevalence of achieving at least $150 \mathrm{~min}$ utes of leisure time physical activity per week was $18.4 \%$, and was highest among males (26.4\%), those in the 18 to 29 age group (23.2\%), those with secondary schooling or more $(21.8 \%)$, those living in urban areas with populations of between 388,000 and 1,027,000 (21\%), those considered to be in the upper middle socioeconomic strata (20\%) and those studying (31.9\%). There were no significant differences between the categories for time spent traveling in motor vehicles.

Associations between time spent traveling in motor vehicles and physical activity

Binary logistic regression analyses of the association between time spent traveling in motor vehicles and physical activity domains are shown in Table 3. In the adjusted model for all participants, those with time spent traveling in motor vehicles of more than 0 minutes were significantly less likely to walk as a means of transportation for at least 150 minutes a week; however, the p-trend was not statistically significant at the alpha error of 0.05 ( $\mathrm{p}$-trend $=0.090$ ). This pattern was similar in the stratified analysis, except in the models for gender (for males) and urbanization levels (for 82,000 to 1,027,000 inhabitants), with a significant $\mathrm{p}$-trend ( $\mathrm{p}$-trends 0.001 and 0.003 , respectively).

Those in the category 'time spent traveling in motor vehicles of more than 0 minutes' were significantly less likely to cycle as a means of transportation at least 150 minutes per week with a p-trend of 0.001 . This pattern was consistent in the stratified models, except for gender (females) (p-trend $=0.468$ ).

No significant associations were found between time spent traveling in motor vehicles and leisure time physical activity in the general and stratified models.

\section{Discussion}

This study indicates that once adjusted for potential confounders, time spent traveling in motor vehicles is inversely associated with active transportation (i.e. walking and cycling) in Colombian adults residing in urban areas. No significant associations were detected with leisure time physical activity. These results are to some extent similar to those reported in other studies mainly those in high income countries, which place a particular 
Table 1

Time spent traveling in motor vehicles per day among 7,313 Colombian adults, by sociodemographic characteristics.

\begin{tabular}{|c|c|c|c|c|c|c|c|}
\hline \multirow[t]{3}{*}{ Characteristics } & \multirow[t]{3}{*}{$n$ * } & \multirow[t]{3}{*}{$\%$} & \multicolumn{4}{|c|}{ Minutes } & \multirow{3}{*}{$\begin{array}{c}\text { p-value } \\
\star \star\end{array}$} \\
\hline & & & 0 & 1 to 59 & 60 to 119 & 120 or more & \\
\hline & & & $\%(95 \% \mathrm{Cl})$ & $\%(95 \% \mathrm{Cl})$ & $\%(95 \% \mathrm{Cl})$ & $\%(95 \% \mathrm{Cl})$ & \\
\hline All participants & 7,313 & 100.00 & $17.7(16.6-18.8)$ & $29.7(28.4-30.9)$ & $25.0(23.8-26.2)$ & $27.6(26.2-28.9)$ & - \\
\hline Gender & & & & & & & $<0.001$ \\
\hline Male & 3,034 & 41.49 & $16.7(15.2-18.2)$ & $24.9(23.2-26.6)$ & $24.3(22.5-26.1)$ & $34.0(32.0-36.1)$ & \\
\hline Female & 4,279 & 58.51 & $18.4(17.1-19.8)$ & $33.0(31.3-34.7)$ & $25.4(24.0-27.0)$ & $23.0(21.4-24.7)$ & \\
\hline Age groups (years) & & & & & & & $<0.001$ \\
\hline $18-29$ & 2,469 & 33.76 & $14.6(13.1-16.2)$ & $31.3(29.2-33.5)$ & $26.7(24.7-28.8)$ & $27.3(25.1-29.6)$ & \\
\hline $30-49$ & 3,282 & 44.88 & $16.9(15.5-18.5)$ & $28.0(26.2-29.7)$ & $24.8(23.1-26.6)$ & $30.1(28.3-32.0)$ & \\
\hline $50-64$ & 1,562 & 21.36 & $24.0(21.7-26.6)$ & $30.5(27.9-33.2)$ & $22.6(20.3-25.1)$ & $22.7(20.2-25.4)$ & \\
\hline Education levels & & & & & & & $<0.001$ \\
\hline Elementary school or less & 1,843 & 25.31 & $27.3(25.0-29.8)$ & $29.0(26.6-31.6)$ & $21.0(18.8-23.3)$ & $22.5(20.1-25.1)$ & \\
\hline Secondary school incomplete & 3,456 & 47.47 & $19.7(18.1-21.3)$ & $29.6(27.8-31.3)$ & $24.5(22.9-26.2)$ & $26.1(24.2-28.0)$ & \\
\hline Secondary school or more & 1,982 & 27.22 & $6.9(5.7-8.2)$ & $30.2(27.9-32.6)$ & $28.8(26.6-31.1)$ & $34.0(31.5-36.6)$ & \\
\hline Urbanization level (inhabitants) & & & & & & & $<0.001$ \\
\hline $82,000-288,000$ & 2,595 & 35.48 & $18.9(17.1-20.8)$ & $46.3(44.1-48.5)$ & $18.8(17.1-20.6)$ & $15.6(14.3-17.4)$ & \\
\hline $388,000-1,027,000$ & 1,858 & 25.41 & $17.7(15.7-19.9)$ & $38.8(36.1-41.6)$ & $24.2(21.8-26.7)$ & $19.1(17.3-21.1)$ & \\
\hline $1,190,000-3,432,000$ & 1,490 & 20.37 & $18.6(16.5-20.9)$ & $29.1(26.6-31.7)$ & $30.4(27.9-33.0)$ & $21.7(19.6-24.0)$ & \\
\hline$\geq 7,760,000$ & 1,370 & 18.73 & $16.2(14.3-18.4)$ & $15.1(13.1-17.2)$ & $25.4(23.1-27.7)$ & $43.2(40.2-46.2)$ & \\
\hline Socioeconomic position & & & & & & & $<0.001$ \\
\hline Low & 2,177 & 29.77 & $25.0(23.0-27.2)$ & $30.0(27.8-32.3)$ & $22.8(20.7-25.0)$ & $22.0(19.9-24.3)$ & \\
\hline Low middle & 967 & 13.22 & $19.4(16.7-22.5)$ & $28.3(25.1-31.6)$ & $25.3(22.2-28.5)$ & $26.9(23.7-30.4)$ & \\
\hline Middle & 826 & 11.29 & $16.2(13.4-19.6)$ & $32.6(29.0-36.3)$ & $25.2(21.9-28.8)$ & $25.8(22.3-29.8)$ & \\
\hline Upper middle & 3,343 & 45.71 & $13.4(12.1-15.0)$ & $29.2(27.4-31.1)$ & $26.0(24.3-27.8)$ & $31.1(29.1-33.3)$ & \\
\hline Occupation & & & & & & & $<0.001$ \\
\hline Working & 4,53 & 61.94 & $14.5(13.3-15.7)$ & $28.5(26.9-30.0)$ & $25.5(24.0-27.0)$ & $31.4(29.8-33.1)$ & \\
\hline Searching for a job & 295 & 4.03 & $25.3(20.1-31.4)$ & $21.9(17.3-27.3)$ & $25.7(20.4-31.7)$ & $26.9(21.3-33.4)$ & \\
\hline Studying & 541 & 7.40 & $10.1(7.5-13.6)$ & $32.9(28.7-37.5)$ & $27.7(23.5-32.4)$ & $29.0(24.5-33.9)$ & \\
\hline Housewife & 1,774 & 24.26 & $27.4(25.0-29.9)$ & $32.7(30.2-35.4)$ & $22.3(20.1-24.6)$ & $17.4(15.3-19.7)$ & \\
\hline Retired & 173 & 2.37 & $18.7(13.2-25.9)$ & $33.8(26.7-41.8)$ & $27.3(20.6-35.1)$ & $20.0(14.1-27.5)$ & \\
\hline
\end{tabular}

* The number of observations can vary due to missing values;

** $p$-values statistically significant at the alpha level of 0.05 .

emphasis on the decline of active transportation associated with increasing private motor vehicle use 19,20,21,22,23,24,25,26,27,28. These results are relevant to public health due to the average duration of motor vehicle trips in some Colombian cities such as Bogota, which showed an increase of $21 \%$ between 2002 and 2011 11. The severity of this problem is exemplified in the fact that the mean time that participants in this study from Bogota spent travelling in motor vehicles per day was 104.7 minutes; $78 \%$ and $50 \%$, higher than in the mid urbanization and lowest urbanization levels, respectively. If this trend is not reversed, the significant negative impact that time spent traveling in motor vehicles has on physical activity levels and other health outcomes will likely continue to escalate 13 . In this sense, providing a greater modal of integration between active means of transportation and public transport could be a viable solution. In addition, improving infrastructure conditions as well as traffic and personal safety would be key elements in increasing the promotion and uptake of active transportation.

The lack of an association between time spent traveling in motor vehicles and leisure time physical activity could potentially be explained by the fact that this type of physical activity is mainly performed on Sundays and holidays in Colombia, when there is less demand for motor vehicle use compared to weekdays. A study supporting 
Table 2

Prevalence of achieving 150 minutes per week of physical activity during leisure time and during transport among 7,313 Colombian adults by sociodemographic characteristics and time spent traveling in motor vehicles.

\begin{tabular}{|c|c|c|c|c|c|c|}
\hline \multirow[t]{2}{*}{ Characteristics } & \multicolumn{2}{|c|}{$\begin{array}{c}\text { Walking as a means of } \\
\text { transport, at least } 150 \\
\text { minutes per week * }\end{array}$} & \multicolumn{2}{|c|}{$\begin{array}{c}\text { Bicycling as a means of } \\
\text { transport, at least } 150 \\
\text { minutes per week * }\end{array}$} & \multicolumn{2}{|c|}{$\begin{array}{l}\text { Achieving } 150 \text { minutes of } \\
\text { physical activity during } \\
\text { leisure time per week } * *\end{array}$} \\
\hline & $\%(95 \% \mathrm{Cl})$ & p-value *** & $\%(95 \% \mathrm{Cl})$ & 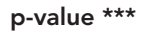 & $\%(95 \% \mathrm{Cl})$ & p-value *** \\
\hline All participants & $34.1(32.8-35.5)$ & - & $4.4(3.8-4.9)$ & - & $18.4(17.4-19.5)$ & - \\
\hline Gender & & $<0.001$ & & $<0.001$ & & $<0.001$ \\
\hline Male & $38.0(36.1-40.1)$ & & $9.1(7.9-10.4)$ & & $26.4(24.6-28.3)$ & \\
\hline Female & $31.36(29.8-33.0)$ & & $1.0(0.7-1.4)$ & & $12.8(11.7-14.0)$ & \\
\hline Age groups (years) & & 0.007 & & 0.646 & & $<0.001$ \\
\hline $18-29$ & $32.2(29.1-33.4)$ & & $4.7(3.8-5.8)$ & & $23.2(21.4-25.9)$ & \\
\hline $30-49$ & $35.5(33.5-37.5)$ & & $4.1(3.4-5.0)$ & & $15.6(14.2-17.0)$ & \\
\hline $50-64$ & $35.7(32.9-38.6)$ & & $4.3(3.3-5.5)$ & & $16.9(14.8-19.2)$ & \\
\hline Education levels & & & & $<0.001$ & & $<0.001$ \\
\hline Elementary school or less & $35.0(32.4-37.7)$ & 0.351 & $5.1(4.0-6.3)$ & & $13.2(11.4-15.2)$ & \\
\hline Secondary school incomplete & $34.5(32.7-36.4)$ & & $5.4(4.5-6.4)$ & & $18.9(17.8-20.4)$ & \\
\hline Secondary school or more & $32.7(30.3-35.1)$ & & $2.2(1.5-3.0)$ & & $21.8(19.8-24.1)$ & \\
\hline Urbanization levels (inhabitants) & & $<0.001$ & & $<0.001$ & & 0.003 \\
\hline $82,000-288,000$ & $41.2(38.5-43.9)$ & & $4.5(3.5-5.9)$ & & $20.7(18.9-22.7)$ & \\
\hline $388,000-1,027,000$ & $27.1(24.8-29.5)$ & & $3.7(2.9-4.9)$ & & $21.0(19.1-23.0)$ & \\
\hline $1,190,000-3,432,000$ & $30.8(28.4-33.3)$ & & $2.4(1.7-3.2)$ & & $16.9(14.6-18.9)$ & \\
\hline$\geq 7,760,000$ & $40.5(31.0-35.7)$ & & $4.3(3.3-5.6)$ & & $17.2(15.0-19.1)$ & \\
\hline Socioeconomic position & & 0.767 & & 0.012 & & 0.009 \\
\hline Low & $34.6(32.2-37.1)$ & & $5.7(4.7-6.9)$ & & $15.9(14.2-17.9)$ & \\
\hline Low middle & $34.9(31.4-38.6)$ & & $3.4(2.3-4.9)$ & & $17.9(15.3-20.8)$ & \\
\hline Middle & $32.3(28.8-36.0)$ & & $4.7(3.2-6.7)$ & & $18.3(15.5-21.6)$ & \\
\hline Upper middle & $34.0(32.2-35.9)$ & & $3.8(3.1-4.6)$ & & $20.0(18.5-21.5)$ & \\
\hline Occupation & & $<0.001$ & & $<0.001$ & & $<0.001$ \\
\hline Working & $36.1(34.5-37.7)$ & & $5.6(4.9-6.5)$ & & $17.0(15.8-18.2)$ & \\
\hline Searching for a job & $40.1(33.8-46.7)$ & & $5.3(3.2-9.0)$ & & $30.5(25.1-36.4)$ & \\
\hline Studying & $31.9(27.6-36.5)$ & & $4.0(2.5-6.5)$ & & $31.9(27.6-36.6)$ & \\
\hline Housewife & $28.8(26.3-31.5)$ & & $1.1(0.7-1.8)$ & & $15.0(13.2-16.9)$ & \\
\hline Retired & $28.5(22.3-35.6)$ & & $2.5(1.1-5.5)$ & & $25.2(19.4-32.1)$ & \\
\hline Time spent traveling in motor vehicles per day (minutes) & & $<0.001$ & & $<0.001$ & & 0.487 \\
\hline 0 & $42.1(38.9-45.4)$ & & $12.3(10.4-14.4)$ & & $17.0(14.8-19.3)$ & \\
\hline 1 to 59 & $28.2(26.2-30.3)$ & & $2.5(1.9-3.2)$ & & $19.1(17.3-20.9)$ & \\
\hline 60 to 119 & $30.5(28.1-33.0)$ & & $2.5(1.7-3.4)$ & & $18.1(16.1-20.2)$ & \\
\hline 120 and more & $38.5(35.9-41.2)$ & & $3.1(2.2-4.2)$ & & $19.1(17.0-21.3)$ & \\
\hline
\end{tabular}

* Walking and bicycling as a means of transport were classified into two categories: reporting at least 150 minutes of active transportation (walking and bicycling) in the last seven days, categorized as yes or no. Only periods of at least 10 minutes were included in the analyses;

** The domain 'leisure time physical activity' was classified into two categories: engaging in at least 150 minutes of physical activity of moderate intensity or 75 minutes of vigorous physical activity in the last seven days, categorized as yes or no. Only sessions of at least 10 minutes were included in the analyses;

*** $p$-values statistically significant at the alpha level of 0.05 . 
Table 3

Binary logistic regression analysis between time spent traveling in motor vehicles and physical activity domains of leisure time and transportation.

\begin{tabular}{|c|c|c|c|c|c|c|}
\hline \multirow[t]{2}{*}{$\begin{array}{l}\text { Time spent traveling in motor } \\
\text { vehicles (minutes) }\end{array}$} & \multicolumn{2}{|c|}{$\begin{array}{c}\text { Walking as a means of } \\
\text { transport, at least } 150 \\
\text { minutes per week * }\end{array}$} & \multicolumn{2}{|c|}{$\begin{array}{c}\text { Bicycling as a means of } \\
\text { transport, at least } 150 \\
\text { minutes per week * }\end{array}$} & \multicolumn{2}{|c|}{$\begin{array}{l}\text { Achieving } 150 \text { minutes of } \\
\text { physical activity during } \\
\text { leisure time per week } * \star\end{array}$} \\
\hline & $\begin{array}{c}\text { Adjusted } \\
\text { Prevalence OR } \\
(95 \% \mathrm{Cl})\end{array}$ & p-trend $* \star \star$ & $\begin{array}{c}\text { Adjusted } \\
\text { Prevalence OR } \\
(95 \% \mathrm{Cl})\end{array}$ & p-trend *** & $\begin{array}{c}\text { Adjusted } \\
\text { Prevalence OR } \\
(95 \% \mathrm{Cl})\end{array}$ & 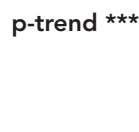 \\
\hline \multicolumn{7}{|l|}{ All participants \# } \\
\hline 0 & Refence & 0.090 & Refence & $<0.001$ & Refence & 0.960 \\
\hline 1 to 59 & $0.57(0.48-0.67)$ & & $0.18(0.13-0.26)$ & & $1.09(0.88-1.34)$ & \\
\hline 60 to 119 & $0.60(0.50-0.72)$ & & $0.17(0.11-0.26)$ & & $1.01(0.81-1.28)$ & \\
\hline 120 or more & $0.76(0.64-0.91)$ & & $0.17(0.11-0.26)$ & & $1.03(0.83-1.29)$ & \\
\hline \multicolumn{7}{|l|}{ Female \#\# } \\
\hline 0 & Refence & 0.219 & Refence & 0.468 & Refence & 0.794 \\
\hline 1 to 59 & $0.52(0.42-0.65)$ & & $0.12(0.04-0.30)$ & & $1.17(0.85-1.63)$ & \\
\hline 60 to 119 & $0.58(0.46-0.75)$ & & $0.36(0.15-0.91)$ & & $1.15(0.82-1.63)$ & \\
\hline 120 or more & $0.77(0.60-0.98)$ & & $0.57(0.23-1.42)$ & & $1.08(0.75-1.57)$ & \\
\hline \multicolumn{7}{|l|}{ Male \#\# } \\
\hline 0 & Refence & 0.001 & Refence & $<0.001$ & Refence & \\
\hline 1 to 59 & $0.64(0.49-0.82)$ & & $0.19(0.13-0.28)$ & & $1.02(0.77-1.36)$ & 0.836 \\
\hline 60 to 119 & $0.61(0.47-0.80)$ & & $0.15(0.09-0.21)$ & & $0.91(0.68-1.22)$ & \\
\hline 120 or more & $0.76(0.59-0.99)$ & & $0.14(0.09-0.22)$ & & $0.99(0.75-1.32)$ & \\
\hline \multicolumn{7}{|l|}{ Age group 18-29 years \#\#\#\# } \\
\hline 0 & Refence & 0.335 & Refence & $<0.001$ & Refence & 0.349 \\
\hline 1 to 59 & $0.51(0.38-0.68)$ & & $0.11(0.07-0.22)$ & & $0.93(0.67-1.31)$ & \\
\hline 60 to 119 & $0.57(0.42-0.78)$ & & $0.11(0.05-0.24)$ & & $0.94(0.66-1.34)$ & \\
\hline 120 or more & $0.70(0.51-0.97)$ & & $0.23(0.12-0.44)$ & & $1.22(0.86-1.73)$ & \\
\hline \multicolumn{7}{|l|}{ Age group $30-64$ years \#\#\# } \\
\hline 0 & Refence & 0.139 & Refence & $<0.001$ & Refence & 0.496 \\
\hline 1 to 59 & $0.57(0.46-0.69)$ & & $0.19(0.13-0.30)$ & & $1.02(0.78-1.32)$ & \\
\hline 60 to 119 & $0.59(0.47-0.74)$ & & $0.21(0.13-0.33)$ & & $1.01(0.76-1.33)$ & \\
\hline 120 or more & $0.79(0.64-0.97)$ & & $0.17(0.11-0.29)$ & & $1.01(0.76-1.33)$ & \\
\hline \multicolumn{7}{|l|}{82,000 to $1,027,000$ inhabitants $\S$} \\
\hline 0 & Refence & 0.003 & Refence & $<0.001$ & Refence & 0.480 \\
\hline 1 to 59 & $0.63(0.51-0.77)$ & & $0.22(0.14-0.34)$ & & $1.05(0.83-1.33)$ & \\
\hline 60 to 119 & $0.56(0.44-0.71)$ & & $0.17(0.10-0.31)$ & & $1.08(0.82-1.42)$ & \\
\hline 120 or more & $0.67(0.53-0.86)$ & & $0.12(0.06-0.24)$ & & $1.09(0.83-1.43)$ & \\
\hline \multicolumn{7}{|l|}{$1,190,000$ inhabitants or more $\S$} \\
\hline 0 & Refence & 0.653 & Refence & $<0.001$ & Refence & 0.655 \\
\hline 1 to 59 & $0.43(0.33-0.57)$ & & $0.12(0.06-0.25)$ & & $1.14(0.83-1.33)$ & \\
\hline 60 to 119 & $0.59(0.46-0.76)$ & & $0.15(0.08-0.27)$ & & $0.96(0.82-1.42)$ & \\
\hline 120 or more & $0.83(0.66-1.06)$ & & $0.18(0.11-0.31)$ & & $1.00(0.83-1.43)$ & \\
\hline \multicolumn{7}{|l|}{ Working or studying §§ } \\
\hline 0 & Refence & 0.151 & Refence & $<0.001$ & Refence & 0.963 \\
\hline 1 to 59 & $0.54(0.44-0.67)$ & & $0.17(0.11-0.24)$ & & $1.14(0.87-1.49)$ & \\
\hline 60 to 119 & $0.55(0.44-0.69)$ & & $0.14(0.08-0.22)$ & & $1.08(0.81-1.42)$ & \\
\hline 120 or more & $0.71(0.57-0.88)$ & & $0.14(0.09-0.22)$ & & $1.06(0.81-1.39)$ & \\
\hline
\end{tabular}

(continues) 


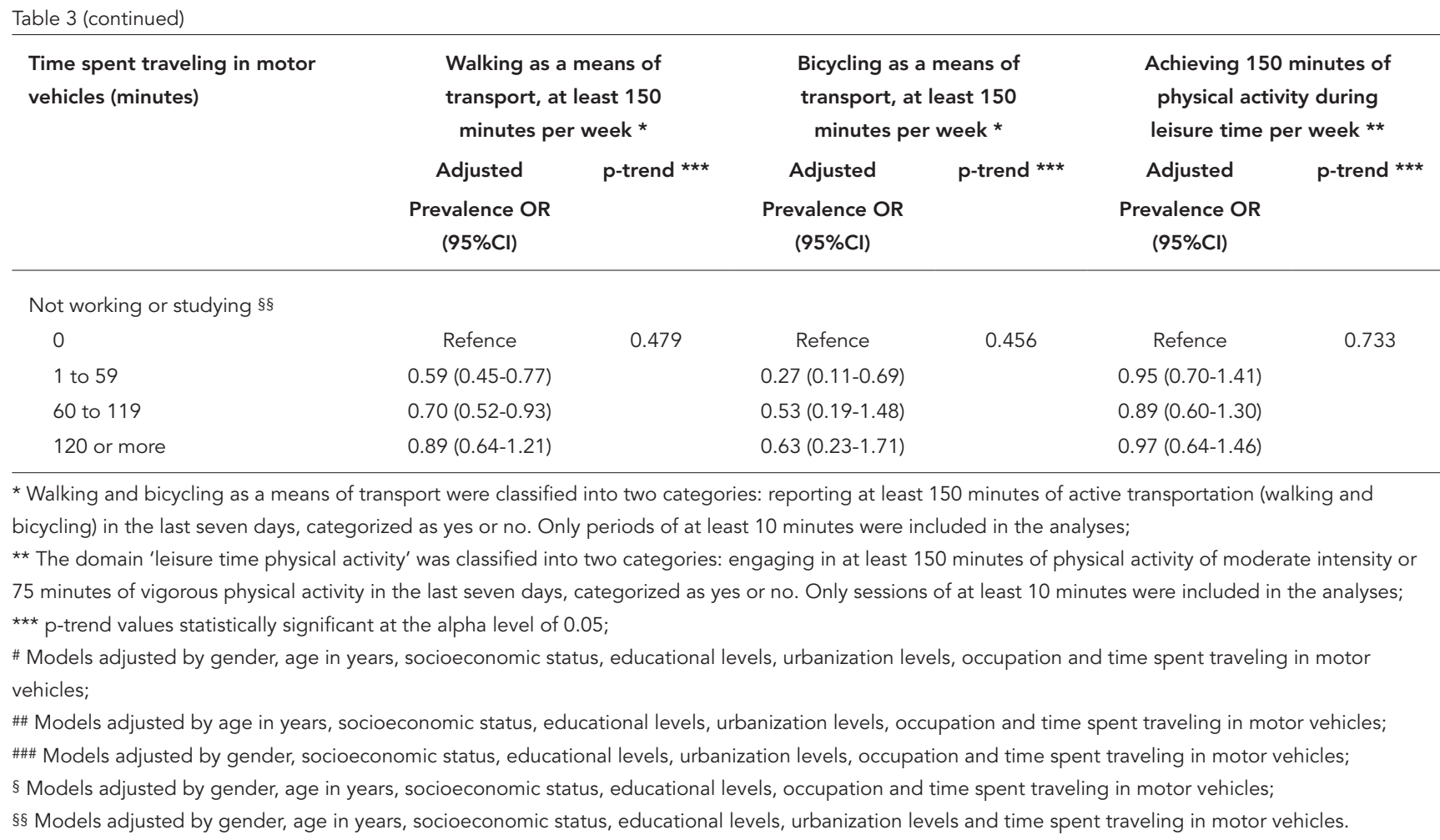

this reasoning was conducted in Cali (Colombia), and found that $55 \%$ of total leisure time physical activity was carried out on Sundays whereas $77 \%$ of the time spent traveling in motor vehicles took place during weekdays 29 . However, it is important to clarify that the information used in this paper did not allow for a distinction between activities performed on weekends and those carried out on weekdays. It is also important to consider that there are social and economic factors that underlie the means of transportation chosen; time spent traveling in motor vehicles represents a need for mobility that is linked to walking and bicycling, while leisure time physical activity is mainly a recreational choice. On the other hand, because of the voluntary and recreational nature of leisure time physical activity, such activities are usually carried out in places such as gyms and parks that are often located near to people's homes or workplaces 30 . This could result in proportionally less time spent in motor vehicles with respect to the duration of physical activity. Moreover, one would not expect leisure time physical activity to be replaced by time spent traveling in motor vehicles because people would still engage in these activities independent of the means of transportation used. Even when these dynamics have been reported in the literature 21,22 , the hypothesis should be tested in future studies in Latin American contexts.
Significant associations were found in the walking models only when stratified by gender (males) and urbanization level (low urbanization levels). Factors such as personal safety and other social behavior norms can explain gender disparities 31. A recent study found that Colombian females perceived more barriers to active transportation than did men: they feel more vulnerable to theft, injuries and personal attacks 32 . This reduces the chance of females using active transportation as a mobility choice, leading to greater use of motor vehicles. With regard to urbanization levels, higher diversity and short walking distances to destinations that are characteristic of low urbanized areas and small cities, have been found to be positively associated with active commuting in Latin American countries 33.

The magnitude of associations is greater in the general 'cycling as a means of transportation' models compared to those found in 'walking as a means of transportation'. In most Colombian cities, bicycle use is restricted by the presence of a uni-modal public transportation system (i.e. public buses and rapid transit buses), whereby such a system is not usually designed to allow for people to travel along with their bicycles. This could explain why time spent traveling in motor vehicles is often associated with active transportation. However, the direction of the association cannot be determined with the study design 
used here. The stratified bicycle models preserve the direction of associations except for the gender-stratified models (females). This could be explained by the low use of bicycles among Colombian women (only $1 \%$ of women reported 150 minutes or more of bicycle use), and it could confirm the gender-related differences in the correlates of physical activity for transportation as previously mentioned in this study and documented in other settings 34 .

To our knowledge, this is the first Latin American study to examine the links between time spent traveling in motor vehicles and two physical activity domains (leisure time physical activity and transport physical activity) using a large nationally representative sample survey.

Some limitations need to be considered to allow for a better interpretation and extrapolation of these results. The observational design of this study does not allow us to draw a causal relationship between time spent traveling in motor vehicles and physical activity. The self-reported measures used to collect the data may lead to errors in judgment or misinterpretation of the questions. For instance, people may recall leisure time physical activity more easily compared to active transportation, which can be underreported due to its potentially habitual nature. The use of IPAQ has been validated for the assessment of physical activity levels, but not for assessing sedentary behaviors, thus time spent traveling in motor vehicles might have been over- or underreported.
Although the relatively large sample size of this study may have increased the possibility of a type I error, the punctual estimations and confidence intervals of the prevalence odds ratio were not relatively close to the null value. Finally, this study cannot rule out residual confusion due to several potential urban environment confounders that were not measured, such as population density and access to destinations.

\section{Conclusions}

This study found negative associations between time spent traveling in motor vehicles and walking and bicycling for transportation, particularly related to gender (females) and urbanization levels (the highest level). This highlights the potential relevance of improving urban mobility to promote active means of transportation. We suggest key interventions that could improve this scenario in Colombia including the creation of an integrated and multi-modal public mass transport system, social improvements in recognizing pedestrians and cyclists, and the development of strategies to improve safety conditions (traffic and personal) in order to reduce gender and urban disparities related to active living. All efforts must mobilize different sectors of society and various disciplines to positively influence decision-making as it relates to active transportation. Regarding the well-known negative impact of prolonged sedentary time, further studies are needed to determine the combined effect of high exposure to time spent traveling in motor vehicles and other sedentary behaviors such as occupational sitting time or recreational sedentary time in the Latin American context. 


\section{Resumo}

Comportamentos sedentários estão associados com menos atividade física. Pouca evidência existe sobre esta associação relacionada ao tempo de viagem na América Latina. Este estudo analisou a associação entre o tempo gasto viajando em veículos a motor e os níveis de atividade física, nos domínios e atividade física de lazer e transporte entre adultos Colombianos em áreas urbanas. Uma análise secundária da Pesquisa Nacional de Nutrição de 2010 foi realizada. O tempo gasto viajando em veículos a motor e atividade física foram avaliados utilizando Questionário Internacional de Atividade Física. Regressões logísticas binárias foram realizados. O tempo gasto viajando em veículos a motor por 120 minutos ou mais foi relatado em $27,6 \%$ da amostra. A prevalência de caminhar ou andar de bicicleta para o transporte de pelo menos 150 minutos por semana foi de 34,0\% e 4,4\%, respectivamente. Alcançar pelo menos 150 minutos de atividade física de lazer em uma semana foi relatado em 18,4\% da amostra. Este estudo sugere associações negativas entre tempo gasto viajando em veículos a motor e transporte ativo, com associações significativas de tendências na análise estratificada. Não houve diferenças significativas encontradas entre tempo gasto viajando em veículos a motor e atividade física de lazer.

Atividade Motora; Estilo de Vida Sedentário; Veículos Automotores

\section{References}

1. Lee IM, Shiroma EJ, Lobelo F, Puska P, Blair SV, Katzmarzyk PT. Effect of physical inactivity on major non-communicable diseases worldwide: an analysis of burden of disease and life expectancy. Lancet 2012; 380:219-29.

2. Instituto Colombiano de Bienestar Familiar; Profamilia. Encuesta nacional de la situación nutricional en Colombia. Bogotá: Instituto Colombiano de Bienestar Familiar/Profamilia; 2010.

3. Frank LD, Andresen MA, Schmid TL. Obesity relationships with community design, physical activity, and time spent in cars. Am J Prev Med 2004; 27:87-96.

4. Owen N, Sugiyama T, Eakin EE, Gardiner PA, Tremblay MS, Sallis JF. Adults' sedentary behavior determinants and interventions. Am J Prev Med 2011; 41:189-96.

5. Hamilton MT, Healy GN, Dunstan DW, Zderic TW, Owen N. Too little exercise and too much sitting: inactivity physiology and the need for new recommendations on sedentary behavior. Curr Cardiovasc Risk Rep 2008; 2:292-8.

\section{Contributors}

D. C. Paez designed the study, conducted the analysis, and the first version of the manuscript, coordinated all the writing process and approved all versions. L. F. Gomez designed the study, contributed to the first draft and gave valuable input on an updated version of the manuscript. C. Mallarino and C. M. Arango provided feedback on the analysis and valuable input on the discussion and approved all updated versions of the manuscript. A. Flórez contributed to the analysis of results, and provided input on the updated versions of the manuscript. A. Nylander conceived the design of the study, conducted the analysis and contributed to the revision of versions of the manuscript. D. C. Parra provided feedback on the analysis and valuable input on the discussion, contributed to writing the manuscript and approval all versions.

\section{Acknowledgments}

The authors thank Logan Mauney for his critical review of the manuscript.
6. Parra DC, Lobelo F, Gómez LF, Rutt C, Schmid T, Brownson RC, et al. Household motor vehicle use and weight status among Colombian adults: are we driving our way towards obesity? Prev Med 2009; 49:179-83.

7. Douglas MJ, Watkins SJ, Gorman DR, Higgins M. Are cars the new tobacco? Am J Public Health 2011; 33:160-9.

8. Florez A, Gomez LF, Parra DC, Cohen DD, Arango $\mathrm{CM}$, Lobelo F. Time spent traveling in motor vehicles and its association with overweight and abdominal obesity in Colombian adults who do not own a car. Prev Med 2012; 54:402-4.

9. United Nations Human Settlements Programme. State of Latin American and Caribbean Cities Report 2012: towards a new urban transition. Nairobi: United Nations Human Settlements Programme; 2012. 
10. Departamento Administrativo Nacional de Estadística. Grandes almacenes e hipermercados minoristas y comercio de vehículos automotores nuevos III trimestre de 2011. http:/ /www.dane.gov.co/files/ investigaciones/boletines/almacenes/bol_gah_III trim11.pdf (accessed on 19/Sep/2013).

11. Secretaria de Movilidad. Movilidad en cifras: 2011. http://www.movilidadbogota.gov.co/hiwebx_archivos/audio_y_video/boletin\%20cifras.pdf (accessed on 19/Sep/2013).

12. Bauman A, Ainsworth BE, Sallis JF, Hagströmer M, Craig CL, Bull FC, et al. The descriptive epidemiology of sitting. A 20-country comparison using the International Physical Activity Questionnaire (IPAQ). Am J Prev Med 2011; 41:228-35.

13. Hoehner CM, Barlow CE, Allen P, Schootman M. Commuting distance, cardiorespiratory fitness, and metabolic risk. Am J Prev Med 2012; 42:571-8.

14. Agrawal AW, Schimek P. Extent and correlates of walking in the USA. Transportation Research Part D. Transport and Environment 2007; 12:548-63.

15. Besser LM, Dannenberg AL. Walking to public transit: steps to help meet physical activity recommendations. Am J Prev Med 2005; 29:273-80.

16. Wener RE, Evans GW. A morning stroll: levels of physical activity in car and mass transit commuting. Environ Behav 2007; 39:62-74.

17. Lachapelle U, Frank L. Transit and health: mode of transport, employer-sponsored public transit pass programs, and physical activity. J Public Health Policy 2009; 30 Suppl 1:S73-94.

18. Goodman A1, Brand C, Ogilvie D; iConnect Consortium. Associations of health, physical activity and weight status with motorised travel and transport carbon dioxide emissions: a cross-sectional, observational study. Environ Health 2012; 11:52.

19. Saelens BE, Sallis JF, Frank LD. Environmental correlates of walking and cycling: findings from the transportation, urban design, and planning literatures. Ann Behav Med 2003; 25:80-91.

20. Bank I-AD. Urban sustainability in Latin America and the Caribbean 2011. http://www.conasamexico. org.mx/conasa/pdf/2011_URBAN-SUSTAINABILI TY-BID.pdf (accessed on 19/Sep/2013).

21. Rydin Y, Bleahu A, Davies M, Dávila JD, Friel S, De Grandis G, et al. Shaping cities for health: complexity and the planning of urban environments in the 21st century. Lancet 2012; 379: 2079-108.

22. Cervero SO, Jacoby E, Gomez L, Neiman A. Influences of built environments on walking and cycling: lessons from Bogota. International Journal of Sustainable Transportation 2009; 3:203-26.

23. Hallal PC, Gomez LF, Parra DC, Lobelo F, Mosquera J, Florindo AA, et al. Lessons learned after 10 years of IPAQ use in Brazil and Colombia. J Phys Act Health 2010; 7 Suppl 2:S259-64.
24. Gomez LF, Parra DC, Lobelo F, Samper B, Moreno J, Jacoby E, et al. Television viewing and its association with overweight in Colombian children: results from the 2005 National Nutrition Survey: a cross sectional study. Int J Behav Nutr Phys Act 2007; 4:41.

25. World Health Organization. Global recommendations on physical activity for health. Geneva: World Health Organization; 2010.

26. Flórez CE, Espinosa F, Sánchez LM, Angulo R. Diseño del indice SISBEN en su tercera versión - SISBEN III - resumen ejecutivo. Versión preliminar. https:// www.sisben.gov.co/Portals/0/Documentos/Docu mentos\%20Tecnicos/02.\%20Resumen\%20Ejecuti vo\%20Sisb\%C3\%A9n\%20III_170210.pdf (accessed on 19/Sep/2013).

27. Dirección de Censos y Demografía, Coordinación de Demografía, Departamento Administrativo Nacional de Estadística. Ficha técnica: revisión y actualización de las estimaciones y proyecciones de población período 1985-2020. http://www.dane. gov.co/files/investigaciones/fichas/Ficha_Estima ciones_Proyecciones_85_2020.pdf (accessed on 19/ Sep/2013).

28. Adams J. Prevalence and socio-demographic correlates of "active transport" in the UK: analysis of the UK time use survey 2005. Prev Med 2010; 50:199203.

29. Gómez LF, Moreno J, Gómez OL, Carvajal R, Parra DC. Physical activity and health-related quality of life among adult women in Cali, Colombia: a crosssectional study. Qual Life Res 2013; 22:2351-8.

30. Hino AAF, Reis RS, Ribeiro IC, Parra DC, Brownson RC, Fermino RC. Using observational methods to evaluate public open spaces and physical activity in Brazil. J Phys Act Health 2010; 7 Suppl 2:S146-54.

31. Bell AC, Garrard J, Swinburn BA. Active transport to work in Australia: is it all downhill from here? Asia Pac J Public Health 2006; 18:62-8.

32. Mosquera J, Parra DC, Gómez LF, Sarmiento O, Schmid T, Jacoby E. An inside look at active transportation in Bogota: a qualitative study. J Phys Act Health 2012; 9:776-85.

33. Arango CM, Paez DC, Reis R, Parra D, Brownson R. Association between the perceived environment and physical activity among adults and older adults in Latin America: a systematic review. Int J Behav Nutr Phys Act 2013, 10:122.

34. Heesch KC, Sahlqvist S, Garrard J. Gender differences in recreational and transport cycling: a cross-sectional mixed-methods comparison of cycling patterns, motivators, and constraints. Int J Behav Nutr Phys Act 2012; 9:106.

Submitted on $21 /$ Nov/2013

Final version resubmitted on 25/Feb/2014

Approved on 28/Apr/2014 